\title{
Okul Öncesi Öğretmen Adaylarının Mesleki Kaygıları İle Aile Katılım Çalışmalarına Yönelik Öz Yeterlilik İnançları Arasındaki İlişkinin İncelenmesi ${ }^{1}$
}

\author{
Zeynep APAYDIN-DEMIRCI ${ }^{2}$ ve Emel ARSLAN ${ }^{3}$
}

\section{$\ddot{O} z$}

$\mathrm{Bu}$ araștırmada okul öncesi öğretmen adaylarının öğretmenlik mesleğine yönelik mesleki kaygıları ile aile katılım çalışmalarına yönelik öz yeterlilik inançları arasındaki ilişkinin incelenmesi amaçlanmıştır. Araştırmanın örneklem grubunu, 2018- 2019 yilında eğitim-öğretim gören Necmettin Erbakan Üniversitesi okul öncesi öğretmen adaylar1 oluşturmaktadır. Araştırmada genel tarama yöntemi kullanılmıştır. Araştırma verileri Ateş ve Kalburan (2016) tarafından geliştirilen “Okul Öncesi Öğretmen Adaylarının Aile Katılım Etkinliklerine İlişkin Öz-Yeterlik İnanç Ölçeğì” ile Köklükaya ve Yıldırım (2016) tarafından geliştirilen "Öğretmenlik Mesleğine Yönelik Kayg1 Ölçeği” ve araştırmacılar tarafından oluşturulan Kişisel bilgi Formu ile toplanmıştır. Elde edilen bulgular sonucunda, okul öncesi öğretmen adaylarının öğretmenlik mesleğine yönelik kayg1 puan ortalamalarının "katılmıyorum" düzeyinde ve aile katılımı çalışmalarına yönelik öz-yeterlilik inanç puan ortalamalarının ise "yeterli hissediyorum" düzeyinde olduğu belirlenmiştir. Aynı zamanda öğrencilerin mesleğe yönelik kayg1 düzeyleri ile aile katılım etkinliklerine ilişkin özyeterlik inançlarının negatif yönde orta düzeyde anlamlı bir ilişkiye sahip olduğu belirlenmiştir. Ayrıca cinsiyet, yaş ve mezun olunan lise değişkenleri açısından bu beceriler anlamlı farklılık göstermezken öğretim kademesi değişkeninin, öğrencilerin mesleğe yönelik kaygı düzeyi arasında anlamlı farklılık gösterdiği belirlenmiştir.

Anabtar Kelimeler: Okul öncesi, Öğretmen adayları, Mesleki kaygı, Aile katılımı, Öz yeterlilik

Investigation of the Relationship between Pre-School Teacher Candidates' Occupational Anxieties and Their Self-Efficacy Beliefs Regarding Family Participation

\begin{abstract}
In this study, it was aimed to research the relationship between pre-school teacher candidates' professional concerns about teaching profession and self-efficacy beliefs towards family involvement activities. The sample group of the study consists of Necmettin Erbakan University pre-school teacher candidates studied in 2018-2019. This study used survey method. The research data were collected with the "Self-Efficacy Belief Scale on Preschool Teacher Candidates' Family Participation Activities" developed by Ateş and Kalburan (2016) and the "Anxiety Scale for the Teaching Profession" developed by Köklükaya and Yıldırım (2016) and the Personal Information Form created by the researchers. As a result of the findings, it was found that the pre-school teacher candidates' anxiety scores for the teaching profession were at the level of "I disagree" and the self-efficacy beliefs for the family involvement activities were "I feel sufficient". In addition, it was found that these skills did not show significant differences in terms of gender, age and high school variables graduated. It was determined that pre-school teacher candidates' professional concerns about teaching profession related to family involvement activities showed significant difference according to teaching level variable.
\end{abstract}

Key Words: Preschool, Teacher candidates, Professional concerns, Family involvement, Self-efficacy

\section{Atıf İçin / Please Cite As:}

Apaydın-Demirci, Z. ve Arslan, E. (2020). Okul öncesi öğretmen adaylarının mesleki kaygıları ile aile katılım çalışmalarına yönelik öz yeterlilik inançları arasındaki ilişkinin incelenmesi. Manas Sosyal Araştırmalar Dergisi, 9(4), 2205-2215.

Geliş Tarihi / Received Date: 28.08.2019

Kabul Tarihi / Accepted Date: 02.07.2020

\footnotetext{
${ }^{1} \mathrm{Bu}$ araştırma 17- 21 Nisan 2019 tarihlerinde düzenlenen "International Human and Civilization Congress From Past To Future" adlı kongrede sözlü bildiri olarak sunulmuştur.

2 Öğr. Gör. - Bilecik Şeyh Edebali Üniversitesi Sağlık Bilimleri Fakültesi, zeynep.demirci@bilecik.edu.tr ORCID: 0000-0001-9788-1585

3 Prof. Dr. - Necmettin Erbakan Üniversitesi Ahmet Keleşoğlu Eğitim Fakültesi, emelarslan@erbakan.edu.tr ORCID: 0000-0002-1294-0855
} 


\section{Giriş}

Aile, çocuğun gelişimini ve eğitimini etkileyen en önemli unsurlardan biridir. Ailelerin, çocuk yetiştirme konusunda geleneksel yaklaşımlardan uzaklaşarak çocuklarını tanıma, çocuklarının gelişimini destekleme ve anne-babalıkla ilgili olumlu duygular geliştirme vb. yaklaşıma sahip olmaları gerekmektedir. Çocukların gelişimlerinin çok yönlü desteklenmesi, okulöncesi eğitimin sadece okulda değil ailede de devamlılığının sağlanması, böylece daha sağlıklı ve üretken bireylerin topluma kazandırılması açısından önemlidir. Bu nedenle okul öncesi eğitim kurumlarında uygulanmakta olan "MEB Okul Öncesi Eğitim Programı" aile katılımı çalışmalarına da yer verir. Okul öncesi eğitim sistemimizde aile katılım çalısmalarının günden güne önem kazandığı göz ardı edilemez.

Aile katılımı; ailelerin eğitilmesi ve eğitime katılımlarının sağlanmasına, desteklenmesine, çocukların deneyimlerinin artmasına, aile ile okul arasındaki iletişimin arttırılmasına ve programların ebeveynlerin katkıları ile zenginleştirilmesine yönelik sistematik bir yaklaşımdır (Cömert ve Güleç, 2004, s. 133). Aile katılım etkinliklerine katılan ailelerin çocuklarının; sosyal beceri düzeyleri artarken, problem davranışları ise azalmaktadır. Ebeveynlerin, aile katılım çalışmaları sayesinde çocukları ile nitelikli zaman geçirebilmeyi öğrendikleri, çocukları ile kurdukları ilişkide daha özgüvenli hareket ettikleri, çocukların akademik başarılarının arttığı ve sosyal-duygusal yönden kendilerini güçlü hissettikleri görülmektedir (Edutopia, 2000, s. 1; Gonzalez-DeHass, Willems, ve Holbein, 2005, s. 99; Yaşar-Ekici, 2017a, s. 543). Okul öncesi eğitimde gerçekleştirilen aile katılımı çalışmalanı, ebeveynlerin okula ve eğitime bakış açılarını geliştirmeyi aynı zamanda çocuklarını sağlıklı bir şekilde desteklemeleri açısından önem taşır. Okulöncesi eğitimde aile katılım çalışmalarının çocuk, okul ve aile açısından çok sayıda olumlu etkisi olduğu bilinmektedir. $\mathrm{Bu}$ sebeple aile katılımı çalışmalarının etkili bir biçimde uygulanması gerekir. Aile katılımı çalısmalarına gereken önemin verilmesi; sağlıklı bir toplumun oluşabilmesi ve okul-aile işbirliğinin etkili olabilmesi için gereklidir (Ekinci-Vural ve Kocabass, 2016, s. 62; Ünüvar, 2010, s. 719).

Ailelerin yanı sıra öğretmenler de toplumumuzda çok önemli bir rol oynamaktadır. Öğretmenler, çocukları dünyanın ve toplumun inşasında aktif bireyler olabilecekleri şekilde eğitirler. Öğrencilerin motivasyonlarını arttrmak, etkili sınıf yönetimini sürdürmek, etkinlikler ve ders planlamak vb. konular öğretmenlerin sorumluluğundadır. Öğretmenlerin, yeterliliğini araştıran çalışmalar, öz-yeterliliğin öğretmenlerin etkililiğinin temel bir belirleyicisi olduğunu göstermektedir (Randi, 2004, s. 1825). Öğretmenler, başarılı bir şekilde mesleğini sürdürebilmesi için nitelikli bir eğitim alması ve mesleğinin gerektirdiği sorumlulukları yerine getirebileceğine yönelik yüksek öz-yeterlik inancına sahip olmalıdır. Bu sebeple öğretmen adaylarının öz-yeterlik inanç düzeyleri, mesleki eğitimlerine devam ederken belirlenmelidir. Aynı zamanda öğretmen yetiştirme programında yapılacak gerekli düzenlemeler yoluyla öğretmen adaylarının yüksek öz-yeterlik inancına sahip olarak mezun olmaları sağlanmalıdır. Yeterlik kavramı bir işi etkili ve verimli şekilde yerine getirebilmek için sahip olunması gereken bilgi, beceri, tutum ve değerlerdir. Öğretmenliğin genel yeterlikleri, bir öğretmenin sahip olması gereken özelliklerin neler olduğu hakkında bilgi vermesidir. Bu manada, öğretmen adaylarının mesleklerinde etkin olabilmeleri için; alanında donanıml, tutum ve davranışlarıyla öğrencilere model olan, etkili iletişim yöntem ve tekniklerini kullanabilen, öğrencileri eğitim-öğretim süreciyle bütünleştirebilen, mesleğini seven ve gelişime açı bireyler olmaları beklenir (Gerçek, 2018, s. 300). Öz-yeterlilik ise kişinin bir işe ya da göreve özgü yeteneğine olan inancıdır (Kesgin, 2006, s. 19). Öz yeterlilik, bir kişinin beklenen sonuçları elde etmek için gerekli davranışı başarılı bir şekilde yerine getirebilme becerisine olan inancı olarak da tanımlanabilir (Bandura, 1997, s. 15). Özyeterliğin özel bir alanı olan aile katulımına yönelik öz-yeterlik inancı, öğretmen adaylarının aile iletişim ve eğitim etkinliklerini etkili ve verimli bir biçimde yapabileceklerine yönelik kendi yeterliklerine ilişkin yargılarıdır (Ateş ve Kalburan, 2016, s. 65). Öğretmenler, okula karşı olumsuz tutum ve deneyimlere sahip ailelerin de var olabileceğini göz önüne alarak istekli ve kararlı uygulamalarla ailelerin eğitim sürecine katıllımlarını sağlamayı önemsemelidirler. Ancak öğretmenlerinde bu süreçte ailelerle sağlıklı iletişim ve ilişkilerin kurulabilmesi için empati, iletişim teknikleri, iş birliği, aileyi bilgilendirmek vb. yeterliliklere sahip olması da gereklidir (ÇamlibelÇakmak, 2010, s. 5). Ogelman (2014, s. 259) yaptuğı çalışmada ev ziyaretleri, öğretmenlerin gerçekleştirmekte en çok zorlandıkları aile katulımı çalışmalarında ilk sırada yer aldığı öğretmenler için gerçekleştirilmesi en rahat ve kolay aile kathlımı çalışması ise bireysel görüşmeler olduğu belirtilmiştir. Ayrıca Türkçe, Sosyal Bilgiler, Müzik ve Resim-İş Öğretmenliği programlarında öğrenim görmekte olan öğretmen adaylarının; Sınıf Öğretmenliği, Okul Öncesi Öğretmenliği ve İlköğretim Matematik Öğretmenliği programlarında öğrenim gören öğretmen adaylarına göre kendilerini daha yeterli olarak algıladıkları belirlenmiştir (Demirtaş, Cömert ve Özer, 2011, s. 105). Eğitim alanında ve bireylerin yetiştirilmesinde oldukça etkili olan öğretmenlerin öz-yeterlik inançları ve bu inançlar üzerinde etkili olan faktörler önem kazanmıştır (Gömleksiz ve Serhatlıŏlu, 2013, s. 204). Ayrıca, özyeterlik inancı yüksek olan bireyler daha az kaygıya, daha fazla özgüvene sahiptirler ve öz-düzenleme becerileri 
de daha yüksektir (Ekinci, 2015, s. 71). Ayrıca öğretmen adaylarının öğretmenlik mesleğine yönelik kaygılarının belirlenmesi, öğretmenlerin nitelikli ve kaliteli bir şekilde yetiştirilmesi açısından önemlidir (Cabı ve Yalçınalp, 2013, s. 87). Mesleki kayg, öğretmen ve öğretmen adaylarının öğretmenlik mesleğine ilişkin olarak öğretme eylemi, kendi mesleki yeterlilikleri, öğrenci ve ebeveyn ilişkileri gibi konularda deneyimledikleri kaygı çeşididir. Kaygılı olma durumunun öğretmenlerde yarattı̆ı gerginlik, yorgunluk ve tükenmişlik sınıf içi beklenmedik tepkilere temel oluşturabilmektedir. Henüz öğretme eylemini gerçekleştirmeye başlamayan öğretmen adaylarının da mesleki kaygıları, eğitim-öğretim dönemlerinde kendini göstermeye başlamaktadır (Gerçek, 2018, s. 299). Öğretmenlerin etkili bir aile katılımı çalışmaları yapabilmesi üzerinde öğretmenin mesleğine yönelik kaygılarının etkisinin olacağı düşünülmektedir.

Bu bilgiler 1şığında, okul öncesi öğretmen adaylarının özellikle mesleki kaygıları ile ilişkilendirilen aile katılım çalışmaları uygulamalarında öğretmen adaylarının öz yeterliliklerinin belirlenmesi araştırma için büyük bir önem taşımaktadır. Bu nedenle araştırma, okul öncesi öğretmen adaylarının mesleki kaygıları ile aile katılım çalısmalarına yönelik öz yeterlilik inançları arasındaki ilişkiyi incelemek amacı ile gerçekleştirilmiştir. Bu amaç doğrultusunda aşağıdaki sorulara yanıt aranmışıtı;

1. Okul öncesi öğretmen adaylarının mesleki kaygıları ve aile katılım çalışmalarına yönelik öz yeterlilik inançları ne düzeydedir?

2. Okul öncesi öğretmen adaylarının mesleki kaygıları ile aile katılım çalışmalarına yönelik öz yeterlilik inançları arasında ilişki var mıdır?

3. Okul öncesi öğretmen adaylarının mesleki kaygıları ile aile katılım çalısmalarına yönelik öz yeterlilik inançları cinsiyet, yaş, mezun olunan lise ve öğretim kademesine göre anlamlı farklılık göstermekte midir?

\section{Yöntem}

Bu çalışmada betimsel araştırma yöntemlerinden, genel tarama modeli uygulanmıştır. Karasar (2012, s. 79) genel tarama modelini, var olan bir durumun, var olduğu şekli ile tanımlanmasını amaçlayan bir araştırma yöntemi olarak açıklamaktadır.

\section{Evren - Örneklem}

Araştırmanın evrenini 2018-2019 yllında eğitim-öğretim gören Necmettin Erbakan Üniversitesi okul öncesi öğretmen adayları oluşturmaktadır. Örneklem grubunu ise araştırmaya gönüllü olarak katılmayı kabul eden 211 öğrenci oluşturmuştur.

\section{Veri Toplama Araçları}

Araştırma verileri Ateş ve Kalburan (2016, s. 62) tarafından geliştirilen "Okul Öncesi Öğretmen Adaylarının Aile Katılım Etkinliklerine İlişkin Öz-Yeterlik İnanç Ölçeğı” ile Köklükaya ve Yıldırım (2016, s. 1454) tarafindan geliştirilen "Öğretmenlik Mesleğine Yönelik Kayg1 Ölçeği” ve araştırmacılar tarafindan oluşturulan Kişisel bilgi Formu ile toplanmıştır. Okul öncesi öğretmen adaylarının mesleki kaygıları ile aile katılım çalışmalarına yönelik öz yeterlilik inançlanı cinsiyet, yaş, mezun olunan lise ve öğretim kademesi açısından incelenmiştir.

Aile Katllhm Etkinliklerine Illiskin Öz-Yeterlik İnanç Ölçeği. Okul öncesi öğretmen adaylarının aile katılımına ilişkin öz-yeterlik inançlarını belirlemek amacıyla Ateş ve Kalburan (2016, s. 62) tarafindan geliştirilmiştir. Ölçek maddelerindeki her ifade için (1) "çok az yeterli hissediyorum" ve (7) "çok yeterli hissediyorum" olarak 7’li Likert tipi bir ölçektir. Ölçek toplamda 21 sorudan oluşmaktadır. Ölçekten elde edilebilecek en yüksek puan 141, en düşük puan ise $0^{\prime}$ dır. Puanın yüksek oluşu bireylerin aile katılım etkinliklerine ilişkin öz-yeterlik inançlarının olumlu yönde değerlendirdiklerini yansıtmaktadır. Ölçeğin geçerlilik ve güvenilirlik çalışmaları sonucunda alfa iç tutarlılık katsayısı 0.94 olarak bulunmuştur (Ateş ve Kalburan, 2016, s. 67).

Öğretmenlik Mesleğine Yönelik Kayg̨ Ölçeğgi. Okul Öncesi Öğretmen Adaylarının öğretmenlik mesleğine yönelik kayg1 düzeylerini belirlemek amacıyla Köklükaya ve Yıldırım (2016, s. 1454) tarafindan geliştirilmiştir. Ölçek "kesinlikle katılıyorum", "katılıyorum", "kararsızım", "katılmıyorum” ve "kesinlikle katılmıyorum" şeklinde 5'li Likert' tipinde ve 35 ifadeden oluşmuştur. İfadeler olumlu ve olumsuz eğilimi ifade edecek şekilde hazırlanmıştır. Bu nedenle 3, 14, 15 ve 22 ifadeler tersinden puanlanmıştır. Ölçekten alınabilecek en yüksek toplam puan $175^{\prime}$ tir. Puanın yüksek olması mesleğe yönelik kaygı düzeyinin düşük olduğunu, puanın düşük olması ise mesleğe yönelik kayg1 düzeyinin yüksek olduğunu göstermektedir. 
Ölçeğin geçerlilik ve güvenilirlik çalışmaları sonucunda alfa iç tutarlılık katsayısı 0.92 olarak bulunmuştur (Köklükaya ve Yıldırım, 2016, s. 1458).

Kişisel Bilgi Formu. Okul öncesi öğretmen adaylarının cinsiyet, yaş, mezun olunan lise ve öğretim kademesi bilgilerini elde etmeye yönelik sorulara yer verilmiştir. Okul öncesi öğretmen adaylarının cinsiyet, yaş, mezun olunan lise ve öğretim kademesi değişkenlerine göre aile katıllım etkinliklerine ilişkin öz-yeterlik inançlarının ve mesleğe yönelik kaygı düzeylerinin anlamlı farklılık gösterip göstermediğini belirlemek üzere hazırlanmış formdur.

\section{Verilerin Analizi}

Araştırma sonucunda elde edilen verilerin analizinde SPSS 20.0 programı kullanılmış olup, verilerin normal dağılıp dağılmadığını belirlemek için Kolmogorov-Simirnov ve Shapiro Wilk testleri yapılmıştır. Veri sayıs1 29'dan az olduğunda Shapiro Wilk, fazla olduğunda ise Kolmogorov-Simirnov testi kullanılmaktadır (Kalayc1, 2008, s. 13). Araştırma veri sayısı 211 olduğu için Kolmogorov-Simirnov testi sonucu incelenmiş olup, ögretmenliğe yönelik mesleki kayg1 ve aile katılımı çalışmalarına yönelik özyeterlilik inancı ölçek verilerinin anlamlılık değeri 0,003 ve 0,000 olarak elde edilmiştir. Bu değerin 0,05’ten küçük olması nedeniyle verilerin normal dağılım (Tablo1) göstermediği belirlenmiştir. Verilerin normal dağıllım göstermediği tespit edilmiş ve non-parametrik testlerden Mann Whitney U, Kuruskall Wallis H, gruplar arasında farkın kaynağını belirlemek amacıyla Bonferronni testi ve Spearman Korelasyon analizi testleri kullanılmışır. Çalışmada anlamlılık düzeyi 0,05 olarak kabul edilmiştir.

Tablo 1. Öğretmenliğe Yönelike Mesleki Kaygı ve Aile Katılimı Calıșmalarna Yönelik Ösyeterlilik Inancı Ölçek Verilerinin Normallik Testi

\begin{tabular}{lccc|ccc}
\hline \multirow{2}{*}{ Grup } & \multicolumn{3}{c|}{ Kolmogorov-Simirnov } & \multicolumn{4}{c}{ Shapiro-Wilk } \\
\cline { 2 - 7 } & İstatistik & sd & $\mathbf{p}$ & İstatistik & sd & p \\
\hline Mesleki Kayg1 & 0.79 & 211 & .003 & 0.967 & 211 & $.000^{*}$ \\
Aile Kat1lim1 & 0.90 & 211 & .000 & 0.948 & 211 & $.000^{*}$ \\
\hline
\end{tabular}

** $\mathrm{p}<0.05$

Tablo 1 incelendiğinde, okul öncesi öğretmen adaylarının öğretmenliğe yönelik mesleki kaygı ve aile katılımı çalışmalarına yönelik öz-yeterlilik inancı ölçeklerinden elde edilen verilerin normal dağılım göstermediği görülmektedir.

\section{Bulgular}

Bu bölümde çalışmanın betimleyici bulgular ve alt problemlerine yönelik bulgulara yer verilmektedir.

Tablo 2. Okul Öncesi Ögrretmen Adaylarna İlişkin Betimleyici Bulgular

\begin{tabular}{|c|c|c|c|}
\hline & & $\mathrm{f}$ & $\%$ \\
\hline \multirow{2}{*}{ Öğrencinin Cinsiyeti } & $K_{1 z}$ & 184 & 87.2 \\
\hline & Erkek & 27 & 12.8 \\
\hline \multirow{3}{*}{ Öğrencinin Yaşı } & $17-20$ & 131 & 62.1 \\
\hline & $21-24$ & 69 & 32.7 \\
\hline & 25 ve üstü & 11 & 5.2 \\
\hline \multirow{4}{*}{ Öğretim Kademesi } & 1. Sinif & 88 & 41.7 \\
\hline & 2. Sinif & 69 & 32.7 \\
\hline & 3.Sinif & 38 & 18 \\
\hline & 4.Sinif & 16 & 7.6 \\
\hline \multirow{6}{*}{ Mezun Olunan Lise } & K1z Meslek Lisesi & 34 & 16.1 \\
\hline & Düz Lise & 18 & 8.5 \\
\hline & Anadolu Lisesi & 115 & 54.5 \\
\hline & Anadolu Öğretmen Lisesi & 9 & 4.3 \\
\hline & Diğer & 33 & 15.6 \\
\hline & Fen Lisesi & 2 & 0.9 \\
\hline
\end{tabular}

Tablo 2 incelendiğinde, araştırmaya 184'ü k1z (\%87,2), 27’si erkek (\%12,8) olmak üzere toplam 211 öğrencinin katıldığı görülmektedir. Yaşlara göre dağlım incelendiğinde ise; öğrencilerin 131\%i (\%62,1) 17 ile 20 yaşları arasında, 69’u (\%32,7) 21 ile 24 yaşları arasında, 11’i $(\% 5,2) 25$ ve üstü yaşlarda olduğu görülmektedir. Araştırmaya katılan öğrencilerin öğretim kademeleri incelendiğinde ise; 88 öğrencinin $(\% 41,7)$ 1. sınıf, 69’u (\%32,7) 2. sınıf, 38'i (\%18) 3. sınıf, 16’sının $(\% 7,6)$ ise 4. sınıf öğrencisi olduğu görülmektedir. Öğrencilerin mezun oldukları liselere bakıldığında ise 34’ü $(\% 16,1)$ kız meslek lisesi, 
18'inin (\%8,5) düz lise, 115'inin (\%54,5) anadolu lisesi, 9'unun (\%4,3) anadolu öğretmen lisesi, 2'sinin $(\% 0,9)$ fen lisesi ve 33 'ünün $(\% 15,6)$ ise diğer liselerden mezun olduğu görülmektedir.

Araştırmada okul öncesi öğretmen adaylarının öğretmenliğe yönelik mesleki kayg1 ve aile katulımı çalışmalarına yönelik öz yeterlilik inancı puan ortalamaları belirlenmiştir. Elde edilen bulgular Tablo 3'de sunulmuştur.

Tablo 3. Okul Öncesi Öğretmen Adaylarmm Ögretmenliğe Yönelik Mesleki Kayg ve Aile Katılım Calısmalarma Yönelik Özyeterlilik Inancı Puanlarna İliskin Değerler

\begin{tabular}{lccccc}
\hline \multicolumn{1}{c}{ Grup } & N & Min. & Max. & Ort. & Ss. \\
\hline Mesleki Kayg1 & 211 & 1.51 & 4.83 & 3.57 & 0.61 \\
Aile Katıllimı Öz-yeterlilik & 211 & 1.48 & 7 & 5.47 & 1.08 \\
\hline
\end{tabular}

Tablo 3'de görüldüğü üzere araştırmaya katılan okul öncesi öğretmen adaylarının öğretmenliğe yönelik mesleki kayg1 düzeyi puan ortalamalarının $(3,57 \pm 0,61)$ ve aile katılımı çalışmalarına yönelik özyeterlilik İnancı puan ortalamalarının ise $(5,47 \pm 1,08)$ olduğu görülmektedir. Bu sonuçlara göre; okul öncesi öğretmen adaylarının öğretmenlik mesleğine yönelik kayg1 puan ortalamaları incelendiğinde "katılmıyorum" düzeyinde oldukları görülmüştür. Aile katılımı çalışmalarına yönelik öz-yeterlilik İnanç puan ortalamaları incelendiğinde ise "yeterli hissediyorum" düzeyinde oldukları belirlenmiştir.

Tablo 4. Kaygı ve Aile Katılım Çalışmalarna Yönelik Öz. Yeterlilik Inanc Durumuna İlişkin Spearman Korelasyon Değerleri

\begin{tabular}{lccc}
\hline & & Mesleki Kayg1 & Aile Kat1lım1 \\
\hline \multirow{2}{*}{ Mesleki Kayg1 } & Korelasyon & 1.000 & $0.528^{* *}$ \\
& $\mathrm{P}$ & & 0.00 \\
& $\mathrm{~N}$ & 211 & 211 \\
\hline \multirow{2}{*}{ Aile Katılımı Özyeterlilik } & Korelasyon & $0.528^{* *}$ & 1.000 \\
& $\mathrm{P}$ & 0.00 & 211 \\
\hline
\end{tabular}

** $\mathrm{p}<0.05$

Tablo 4 incelendiğinde öğrencilerin mesleğe yönelik kayg1 durumu ve aile katılım çalışmalarına yönelik öz yeterlilik inanç durumunun istatistiksel açıdan negatif yönde ve orta düzeyde anlamlı bir ilişkiye sahip olduğu görülmektedir ( $\mathrm{r}=0.528, \mathrm{p}<0.01)$. Bu sonuca göre, araştırmaya katılan öğrencilerin öğretmenlik mesleğine yönelik kaygı durumu ve aile katılım çalışmalarına yönelik öz yeterlilik inançlarının birbirleri ile ilişkili olduğu söylenebilir. Aile Katılım Etkinliklerine İlişkin Öz-Yeterlik İnanç Ölçeğinden alınan puanın yüksek oluşu bireylerin aile katılım etkinliklerine ilişkin öz-yeterlik inançlarının olumlu yönde olduğunu gösterirken, Öğretmenlik Mesleğine Yönelik Kaygı Ölçeğinden alınan puanın yüksek olması mesleğe yönelik kaygı düzeyinin düşük olduğunu göstermektedir. Bu nedenle " $r$ " değeri pozitif olmasına rağmen ölçeklerin puanlanma biçimi sebebiyle öğrencilerin mesleğe yönelik kaygı durumu ve aile katulım çalışmalarına yönelik öz yeterlilik inanç durumunun negatif yönde anlamlı bir ilişkiye sahip olduğu söylenebilir.

Tablo 5. Okul Öncesi Ögretmen Adaylarn Mesleki Kaygı ve Aile Katılım Özyeterlilik İnancmın Cinsiyet Değgsskenine Göre Farkhlik Gösterip Göstermediğine Illiskin Mann Whitney-U Testi Bulguları

\begin{tabular}{|c|c|c|c|c|c|c|}
\hline & Cinsiyet & $\mathbf{N}$ & S1ra Ortalamas1 & Sira Toplamı & $\mathrm{U}$ & $\mathbf{P}$ \\
\hline Mesleki & $K_{1 z}$ & 184 & 105.18 & 19353.00 & 2333.00 & 0.610 \\
\hline Kayg1 & Erkek & 27 & 111.59 & 3013.00 & & \\
\hline \multirow{2}{*}{$\begin{array}{l}\text { Aile Katılımı } \\
\text { Özyeterlilik }\end{array}$} & $K_{1 z}$ & 184 & 105.63 & 19436.00 & 2416.50 & 0.820 \\
\hline & Erkek & 27 & 108.50 & 2929.50 & & \\
\hline
\end{tabular}

Tablo 5 incelendiğinde öğrencilerin mesleğe yönelik kayg1 durumunun ( $U=2333.00, p>0.05)$ cinsiyet değişkenine göre anlamlı farklılık göstermediği, aynı şekilde öğrencilerin aile katılım çalışmalarına yönelik Öz-yeterlilik inanç durumunun da $(\mathrm{U}=2416.50, \mathrm{p}>0.05)$ cinsiyet değişkeni açısından istatistiksel olarak anlamlı bir farklılık olmadığı belirlenmiştir. 
Okul Öncesi Öğretmen Adaylarının Mesleki Kaygıları İle Aile Katılım Çalışmalarına Yönelik Öz Yeterlilik İnançları Arasındaki İlişkinin İncelenmesi

Tablo 6. Okul Öncesi Ögretmen Adaylarn Mesleğe Yönelik Kaygi ve Aile Katılım Calışmalarna Yönelik Öz.

Yeterlilik Inancmmn Yaş Değiskenine Göre Farklılı Gösterip Göstermediüine İlişkin Kruskal Wallis Testi Bulgular

\begin{tabular}{|c|c|c|c|c|c|c|}
\hline & Yaş & $\mathbf{N}$ & Sira Ortalaması & SD & $\mathbf{X}^{2}$ & $\mathrm{p}$ \\
\hline \multirow{3}{*}{ Mesleki Kaygı } & $17-20$ & 131 & 104.64 & 2 & 1.023 & 0.599 \\
\hline & $21-24$ & 69 & 105.72 & & & \\
\hline & 25 ve üstü & 11 & 124.00 & & & \\
\hline \multirow{3}{*}{ Aile Katılımı Özyeterlilik } & $17-20$ & 131 & 105.11 & 2 & 0.330 & 0.848 \\
\hline & $21-24$ & 69 & 108.84 & & & \\
\hline & 25 ve üstü & 11 & 98.82 & & & \\
\hline
\end{tabular}

$* \mathrm{p}<0.05$

Tablo 6. incelendiğinde öğrencilerin mesleğe yönelik kayg1 durumu $\left(\chi 2_{(2)}=8.650, \quad \mathrm{p}>0.05\right)$ ve öğrencilerin aile katılım çalışmalarına yönelik öz yeterlilik inanç durumunun $\left(\chi_{(2)}=4.664, p>0.05\right)$ yaş değişkenine göre istatistiksel açıdan anlamlı bir farklılık göstermediği belirlenmiştir.

Tablo 7. Okul Öncesi Ögrretmen Adaylarn Mesleğe Yönelik Kaygı ve Aile Katılım Calısmalarna Yönelik Öz. Yeterlilik Inancınn Öğretim Kademesi Değişkenine Göre Farkhlik Gösterip Göstermediğine Ilişkin Kruskal Wallis Testi Bulgular

\begin{tabular}{|c|c|c|c|c|c|c|}
\hline & Öğretim Kademesi & $\mathbf{N}$ & Sira Ortalaması & SD & $\mathrm{X}^{2}$ & $\mathrm{p}$ \\
\hline \multirow{4}{*}{ Mesleki Kayg1 } & 1. Sinif & 88 & 117.18 & 3 & 8.650 & $0.034 *$ \\
\hline & 2. Sinif & 69 & 89.22 & & & \\
\hline & 3. Sinif & 38 & 112.32 & & & \\
\hline & 4. Sinif & 16 & 101.88 & & & \\
\hline \multirow{4}{*}{ Aile Katılımı Özyeterlilik } & 1. Sinif & 88 & 113.55 & 3 & 4.664 & 0.198 \\
\hline & 2. Sinif & 69 & 93.28 & & & \\
\hline & 3. Sinif & 38 & 108.33 & & & \\
\hline & 4. Sinif & 16 & 113.84 & & & \\
\hline
\end{tabular}

$* \mathrm{p}<0.05$

Tablo 7. incelendiğinde öğrencilerin mesleğe yönelik kayg1 $(\chi 2(4)=8.650, \quad p<0.05)$ durumunun öğretim kademesi değişkenine göre istatistiksel açıdan anlamlı bir farklılık gösterdiği bulunmuştur. Öğrencilerin aile katılım çalışmalarına yönelik öz-yeterlilik inanç durumunun $(\chi 2(4)=4.664, \mathrm{p}>0.05)$ ise öğrencilerin öğrenim gördükleri öğretim kademesi değişkenine göre istatistiksel açıdan anlamlı bir farklılık göstermediği belirlenmiştir.

Gruplar arasındaki farkın kaynağını belirlemek için Bonferroni düzeltmesi yapılmıştır (Uysal, 2018, s. 179). Buna göre değişken sayısı 4 olduğu için Bonferroni düzeltmesi; p değeri, değişken sayısına bölünerek $(0,05 / 4=0,0125)$ bulunmuştur. Farkın kaynağını bulmak için yapılan Mann-Whitney U testi sonuçlarına göre 1. sınıf ile 2. sinıf öğrenci $(p=0,004)$ grubundan kaynaklandığ1 belirlenmiştir. 2. sınıf öğrencilerin mesleğe yönelik kayg1 düzeyleri 1. sınıf öğrencilerine göre daha yüksek bulunmuştur.

Tablo 8. Okul Öncesi Öğretmen Adaylarn Mesleğe Yönelik Kaygı ve Aile Katılım Calısmalarna Yönelik Öz. Yeterlilik Inancmon Mezun Olunan Lise Değiskeenine Göre Farklilık Gösterip Göstermediğine İlişkin Kruskal Wallis Testi Bulgular

\begin{tabular}{|c|c|c|c|c|c|c|}
\hline & Mezun Olduğu Lise & $\mathbf{N}$ & S1ra Ortalaması & SD & $\mathrm{X}^{2}$ & $\mathrm{p}$ \\
\hline \multirow{6}{*}{ Mesleki Kayg1 } & Kız Meslek & 34 & 105.26 & 5 & 0.584 & 0.989 \\
\hline & Düz Lise & 18 & 102.86 & & & \\
\hline & Anadolu Lisesi & 115 & 104.41 & & & \\
\hline & Anadolu Öğr. & 9 & 109.33 & & & \\
\hline & Diğer & 33 & 112.89 & & & \\
\hline & Fen Lisesi & 2 & 109.25 & & & \\
\hline \multirow{6}{*}{$\begin{array}{l}\text { Aile Katılımı } \\
\text { Özyeterlilik }\end{array}$} & Kız Meslek & 34 & 117.19 & 5 & 4.585 & 0.469 \\
\hline & Düz Lise & 18 & 117.00 & & & \\
\hline & Anadolu Lisesi & 115 & 101.14 & & & \\
\hline & Anadolu Öğr. & 9 & 96.44 & & & \\
\hline & Diğer & 33 & 111.36 & & & \\
\hline & Fen Lisesi & 2 & 50.50 & & & \\
\hline
\end{tabular}


Tablo 8 incelendiğinde öğrencilerin mesleğe yönelik kayg1 durumunun $(\chi 2(2)=8.650, \quad \mathrm{p}>0.05)$ ve öğrencilerin aile katılım çalışmalarına yönelik öz yeterlilik inanç durumunun $(\chi 2(2)=4.664, p>0.05)$ mezun olunan lise değişkenine göre istatistiksel açıdan anlamlı bir farklılık göstermediği bulunmuştur.

\section{Tartışma, Sonuç ve Öneriler}

$\mathrm{Bu}$ araştırma, okul öncesi öğretmen adaylarının öğretmenlik mesleğine yönelik mesleki kaygıları ile aile katılım çalışmalarına yönelik öz yeterlilik inançları arasındaki ilişkinin incelenmesi amacıyla yapılmıştır. Okul öncesi öğretmen adaylarının öğretmenlik mesleğine yönelik kaygı puan ortalamaları incelendiğinde "katılmıyorum" düzeyinde oldukları görülmüştür. Aile katıllımı çalışmalarına yönelik öz-yeterlilik İnanç puan ortalamaları incelendiğinde ise "yeterli hissediyorum" düzeyinde oldukları belirlenmiştir. Okul öncesi öğretmen adaylarının öğretmenlik mesleğine yönelik kayg1 düzeylerinin az olduğu, aile katılımı çalışmalarına yönelik öz-yeterlilik İnanç düzey puan ortalamalarının ise yüksek olduğu söylenebilir. Okul öncesi öğretmen adaylarının öğretmenlik mesleğine yönelik kayg1 düzeylerine yönelik araştırma sonucumuzu destekleyen birçok çalışma bulunmaktadır. Yapılan birçok araştırma sonucunda öğretmen adaylarının, kaygı düzeylerinin düşük olduğu bulunmuştur (Doğan ve Çoban, 2009, s.157; GümrükçüBilgici ve Deniz, 2016b, s. 53; Kalemoğlu-Varol, Erbaş ve Ünlü, 2014, s. 113; Köklükaya ve GüvenYıldırım, 2016, s. 1454). Okul öncesi öğretmen adaylarının aile katılım çalışmalarına yönelik öz yeterlilik inançlarına yönelik çeşitli çalışma sonuçları bulunmaktadır. Okul öncesi öğretmen adaylarının aile katılım çalışmalarına ilişkin öz-yeterliklerinin orta düzeyde olduğunu belirleyen araştırmalar mevcuttur (Ateş ve Cevher-Kalburan 2016, s. 62; Özen, 2018, s. 34). Ayrıca Yeşilyurt (2013, s. 88) yaptı̆̆ araştırma sonucunda, öğretmen adaylarının öz-yeterlik alg1 düzeyinin istenilen seviyede olduğunu bulmuştur. Gömleksiz ve Serhatlığlu (2013, s. 201) ise çalışmasında okul öncesi öğretmenlerinin öz-yeterlik inançlarının yüksek düzeyde olduğunu belirlemiştir.

Okul öncesi öğretmen adaylarının öğretmenlik mesleğine yönelik kaygı durumu ve aile katılım çalışmalarına yönelik öz yeterlilik inanç durumunun istatistiksel açıdan negatif yönde ve orta düzeyde anlamlı bir ilişkiye sahip olduğu görülmektedir. Bu sonuca göre okul öncesi öğretmen adaylarının aile katılım çalışmalarına yönelik öz yeterlilik inançları arttıkça, mesleki kaygılarının da azaldığı söylenebilir. Aynı zamanda okul öncesi öğretmen adaylarının aile katılımı çalışmalarına yönelik öz-yeterlilikleri üzerinde mesleklerine yönelik kaygılarının etkisinin olduğu söylenebilir. Deniz ve Tican (2017, s. 1838) öz-yeterlik inanç ve mesleki kaygı durumları arasında pozitif düşük düzeyde korelasyon olduğunu belirlemiştir. Öğretmen adaylarının öğretmenlik öz-yeterlik inançları arttıkça, mesleki kaygılarının da azaldığı ve öğretmen adaylarının öğretmenlik mesleğine ilişkin kaygılarının artması, gelecekte kariyerlerinde ilerlemelerine ilişkin karşılaşabilecekleri sorunların üstesinden gelebilme ve beklenmedik değişimlere uyum sağlayabilme konusundaki inançlarının azaldığı belirlenmiştir (Gerçek, 2018, s. 297). Öğretmen adaylarının öz-yeterlik alg1ları ile mesleki kaygıları arasında negatif yönlü bir ilişki olduğu, öz-yeterlik algıları yüksek olan öğretmen adaylarının mesleki kayg1 düzeylerinin düşük olduğu ve öz-yeterlik algısının mesleki kayg1 düzeyini anlamlı olarak yordadığı bulunmuştur (Kahraman ve Çelik, 2019, s. 353). Kafkas, Açak, Çoban ve Karademir (2010, s. 368) in öğretmen adayları ile yaptı̆̆1 çalısmada da öz-yeterlik ve mesleki kayg1 durumları arasında orta düzeyde korelasyon olduğu bulunmuştur.

Okul öncesi öğretmen adaylarının öğretmenlik mesleğine yönelik mesleki kayg1 ve aile katılımı çalışmalarına yönelik öz-yeterlilik inancının, cinsiyet değişkenine göre anlamlı bir farklılık göstermediği bulunmuştur. Araştırmamızı destekleyen birçok çalışma bulunmaktadır. Yenice (2012, s. 36) yaptı̆̆1 araştırmada fen bilgisi, sosyal bilgiler ve sınıf öğretmeni adaylarının öz-yeterlik düzeylerinin cinsiyet değişkenine göre anlamlı farklılık göstermediği bulunmuştur. Kahraman ve Çelik’in (2019, s. 358) yaptı̆̆1 çalışmada da öğretmen adaylarının öz-yeterlik alg1 düzeyleri cinsiyete göre anlamlı farklılık göstermemektedir. Özen’in (2018, s. 34) öğretmenlerle yaptı̆̆ araştırmada ise öğretmenlerin cinsiyete değişkenine göre aile katılım çalışmalarında öz yeterlilik inançlarında istatistiksel olarak anlamlı fark olmadığı bulunmuştur. Taşkın ve Hacıömeroğlu (2010, s. 63) sınıf öğretmeni adaylarının öz-yeterlik inançlarının cinsiyetlerine göre farklılaşmadığını bulmuştur. Gömleksiz ve Serhatlıŏglu (2013, s. 201) okul öncesi öğretmenlerinin öz-yeterlik inançlarını cinsiyetlerine göre farklılaşmadığı belirlenmiştir. Araştırmamızı desteklemeyen çalışmalar da mevcuttur. Demirtaş, Cömert ve Özer (2011, s. 97) yaptıkları çalışmada ise öğretmen adaylarının öz-yeterlik algılarının cinsiyet değişkenine göre erkeklerin lehine anlamlı farklılık oluşturduğu bulunmuştur. Yeşilyurt (2013, s. 88), Dolapçı ve Demirtaş (2016, s. 141), Uygun, Avaroğulları ve Oran (2016, s. 417), Kafkas, Açak, Çoban ve Karademir (2010, s. 368) öğretmen adaylarının öz-yeterlik algı düzeyleri arasında cinsiyet değişkeni açısından erkeklerin lehine farklılık bulunmuştur. Çapri ve Çelikkaleli (2008, s. 33) öğretmen adaylarının yeterlik inançları üzerinde, cinsiyet 
açısından kızlar lehine anlamlı farklılık gösterdiğini belirlemiştir. Deniz ve Tican (2017, s. 1848) öğretmen adaylarının öz-yeterlik inanç algılarının cinsiyete göre anlamlı bir farklılık gösterdiğini belirlemiş ve kadın öğretmen adaylarının "olumlu sınıf ortamı oluşturma" ve "akademik gelişim" algıları, erkek öğretmen adaylarına göre daha yüksek bulunmuştur. Alan yazında cinsiyet değişkenine göre okul öncesi öğretmen adaylarının mesleki kaygılarına ilişkin çeşitli sonuçlar bulunmuştur. Gümrükçü-Bilgici ve Deniz (2016a, s. 53) yaptıkları araştırma sonucunda, kadın okul öncesi öğretmen adaylarının atanma merkezli kaygılarının, erkek okul öncesi öğretmen adaylarının ise görev merkezli kaygılarının daha yüksek olduğunu belirlemiştir. Ayrıca, Doğan ve Çoban'ın (2009, s. 166) yaptığı araştırmada öğretmen adaylarının cinsiyet açısından kayg1 düzeyleri arasında anlamlı bir farklılık olmadığı bulunmuştur. Gümrükçü-Bilgici ve Deniz (2016b, s. 93) yaptığı araştırmada okul öncesi öğretmen adaylarının Ben Merkezli Kaygı, Görev Merkezli Kayg1, Öğrenci Merkezli Kayg1 ve toplam kayg1 puanı düzeylerinin hiçbirisine cinsiyetin etkisinin bulunmadığ1 belirlenmiştir. Dursun ve Karagün'ün (2012, s. 93) yaptığı çalışmada beden eğitimi öğrencilerinin mesleki kaygılarının cinsiyet değişkeni açısından anlamlı bir farklılık göstermediği bulunmuştur. Kalemoğlu-Varol, Erbaş ve Ünlü (2014, s. 113) yaptıkları çalışmada öğretmen adaylarının mesleki kaygı düzeyleri ile mesleğe yönelik tutumlarının cinsiyet değişkenine göre anlamlı farklılık oluşturmadığı belirlenmiştir. Türkdoğan'ın (2014, s. 101) çalışmasında ise kız öğretmen adaylarının kayg1 puanları, erkek öğretmen adaylarına göre anlamlı şekilde daha yüksek düzeyde olduğu bulunmuştur. Marso ve Pigge, (1990, s. 2) öğretmen adaylarının mesleki kayg1 düzeylerinin cinsiyet değişkenine göre anlamlı farklılık gösterdiği belirlenmiştir. Jianfang $(2018$, s. 2) ise öğretmen adaylarının kaygılarını incelediğinde kadın katılımcıların, erkeklerden daha fazla endişe duyduğunu belirlemiştir.

Okul öncesi öğretmen adaylarının öğretmenlik mesleğine yönelik kayg1 durumu ve öğrencilerin aile katılım çalışmalarına yönelik öz yeterlilik inanç durumunun yaş değişkenine göre istatistiksel açıdan anlamlı bir farklılık göstermediği belirlenmiştir. Gümrükçü-Bilgici ve Deniz (2016a, s. 65) yaptığ çalışmada ise 1819 yaş aralığındaki okul öncesi öğretmen adaylarının mesleki kaygılarının daha büyük yaşlardaki okul öncesi ögretmen adaylarından düşük olduğu belirlenmiştir. Öğretmen adaylarının öğretmenliğe yönelik öz yeterlik inançları ise yaşa göre farklılaşmamaktadır (Yaşar-Ekici, 2017b, s. 543).

Okul öncesi öğretmen adaylarının öğretmenlik mesleğine yönelik kayg1 durumunun öğretim kademesine göre istatistiksel açıdan anlamlı bir farkllılı gösterdiği bulunmuştur. 2. sınıf öğrencilerin mesleğe yönelik kaygı düzeyleri 1. sınıf öğrencilerine göre daha yüksek bulunmuştur. Bu anlamlı farklılığın 2. sınıfta mesleki derslerin 1. sınıfa göre daha fazla olması ile birlikte öğrencilerin öğretmenlik mesleğinin önemine olan farkındalıklarının artması sonucu kaygılarının da arttığı söylenebilir. Öğrencilerin aile katılım çalışmalarına yönelik öz yeterlilik inanç durumunun ise öğrencilerin öğrenim gördükleri öğretim kademesine göre istatistiksel açıdan anlamlı bir farkllılk göstermediği belirlenmiştir. Gümrükçü-Bilgici ve Deniz (2016b, s. 2353) yaptı̆̆ı çalısmada üçüncü sınıfta öğrenim gören okul öncesi öğretmen adaylarının birinci sınıfta öğrenim gören okul öncesi öğretmen adaylarından daha fazla kaygı taşıdığı belirlenmiştir. Yapılan bir başka çalışmada ise 3. sınıf okul öncesi öğretmen adaylarının öz-yeterlik inanç puanlarının 1. sınıflara göre yüksek olduğu ve öğretmen adaylarının öz-yeterlik puanları arasında 3. sınıflar lehine anlamlı fark olduğu görülmüştür (Ekinci-Vural ve Hamurcu, 2008, s. 24). Ayrıca yapılan farklı araştırmalarda, fen bilgisi, sosyal bilgiler ve sınıf öğretmeni adaylarının da öz-yeterlik düzeylerinin sınıf düzeyi değişkenine göre anlamlı farkl1lık göstermediği bulunmuştur (Yenice, 2012, s. 36). Kayg1 düzeylerinin, öğretmen adaylarının öğrenim gördükleri sınıf düzeyine göre anlamlı bir farklılaşma göstermediği çalışmalar da bulunmaktadır (Türkdoğan, 2014, s. 85; Jianfang, 2008, s. 132).

Okul öncesi öğretmen adaylarının öğretmenlik mesleğine yönelik kaygı durumunun ve öğrencilerin aile katılım çalışmalarına yönelik öz yeterlilik inanç durumunun mezun olunan lise değişkenine göre istatistiksel açıdan anlamlı bir farklılık göstermediği bulunmuştur. Bu sonuca göre lisansta verilen mesleki eğitimlerin, mesleğe yönelik kayg1 ve öz-yeterlilik için lise eğitimine nazaran daha belirleyici olduğu söylenebilir. Araştırma sonucumuzu destekleyen birçok çalışma bulunmaktadır. Dursun ve Karagün (2012, s. 93) yaptığı çalışmada beden eğitimi öğrencilerinin mesleki kaygı düzeylerinde, mezun oldukları lise türü açısından anlamlı bir farkllık bulunmamıştır. Ayrıca fen bilgisi, sosyal bilgiler ve sınıf öğretmeni adaylarının öz-yeterlik düzeylerinin mezun olunan lise türü değişkenine göre anlamlı farkll1lk göstermediği bulunmuştur (Yenice, 2012, s. 36). Kayg1 düzeylerinin, öğretmen adaylarının mezun oldukları lise türüne göre herhangi bir anlamlı farklılık göstermediği anlaşılmaktadır (Gümrükçü-Bilgici ve Deniz 2016b, s. 2353; Özen, 2018, s. 34; Türkdoğan, s. 2014). Deniz ve Ticanın (2017, s. 1849) yaptığı çalışmada ise öğretmen adaylarının öz-yeterlik inançları ve mesleki kayg1 düzeylerinin mezun olunan lise türleri göre anlamlı farklılık gösterdiği, öğretmen adaylarının mezun olunan lise türüne göre Anadolu Lisesi 
mezunlarının "etkili öğrenme-öğretme süreci" hazırlama konusunda Anadolu öğretmen lisesi ve diğer lise mezunlarından daha üst düzeyde öz-yeterlik inancına sahip olduğu belirlenmiştir. Ayrıca Beden eğitimi öğretmen adaylarının öz-yeterlik durumunun lise türü değişkenine göre anlamlı farklılık gösterdiği, meslek lisesi mezunların öz yeterlilik puanlarının düşük olduğu bulunmuştur (Kafkas, Açak, Çoban ve Karademir, 2010, s. 105).

$\mathrm{Bu}$ araştırma sonuçlanına göre yapılacak çalışmalar için öneriler aşağıda sunulmuştur.

1. Okul öncesi öğretmen adaylarının mesleki kaygıları dikkate alınarak kaygılarını azaltııı ve aile katılımı çalışmalarına yönelik öz yeterlilik inancını artırıcı çalışmalar yapılabilir.

2. Okul öncesi öğretmen adaylanının lisans eğitimi sürecinde mesleki kaygının azaltılabilmesi ve aile katılımı çalışmalarına yönelik öz-yeterliliğin arttırlabilmesi için okullarda uygulama derslerine daha fazla ağırlık verilebilir.

3. Okul öncesi öğretmen adaylarının mesleki kaygılarını azaltmak ve aile katılımı çalışmalarına yönelik öz-yeterlilik inançlarını desteklemek amacıyla okul öncesi eğitim kurumlarında görev yapan öğretmenlerle ortak çalışmalar yapılabilir.

4. Okul öncesi Öğretmen adaylarının lisans eğitimi süresince kurs, seminer, konferans gibi akademik etkinliklere katılmaları teşvik edilebilir. Bu sayede çeşitli bölgelerde ve kurumlarda görev yapan okul öncesi öğretmenleri, okul yöneticileri, çeşitli üniversitelerde öğrenim gören öğretmen adayları ile etkileşim kurmaları desteklenebilir.

5. Öğrencilerin mesleğe yönelik kaygı düzeylerini minimuma indirebilecek rehberlik çalısmaları yapilabilir.

6. Okul öncesi öğretmen adaylarının mesleki kaygı ve aile katılım çalışmalarına yönelik öz-yeterlilik inançları ile ilgili araştırmalar farklı üniversitelerdeki okul öncesi öğretmen adayları ile de yapilabilir.

\section{Etik Beyan}

"Okul Öncesi Ögretmen Adaylarmm Mesleki Kayglan İle Aile Katılim Çallsmalarna Yönelik Öz Yeterlilik İnançlar Arasındaki Ilişkinin İncelenmesi" başlıklı çalışmanın yazım sürecinde bilimsel, etik ve alıntı kurallarına uyulmuş; toplanan veriler üzerinde herhangi bir tahrifat yapılmamış ve bu çalışma herhangi başka bir akademik yayın ortamına değerlendirme için gönderilmemiştir.

\section{Kaynakça}

Ateş, Ö. ve Cevher-Kalburan, N. (2016). Okul öncesi öğretmen adaylarının aile katılım çalışmalarına yönelik özyeterlik inançlarının incelenmesi. Akademik Bakıs Dergisi, 55(5), 62-88.

Bandura, A. (1997). Self-efficacy: The exercise of control. New York: W.H. Freeman and Company.

Cabı, E. ve Yalçınalp, S. (2013). öğretmen adaylarına yönelik mesleki kaygı ölçeği (mkö): geçerlik ve güvenirlik çalışması. Hacettepe Üniversitesi Eg̈itim Fakültesi Dergisi, 44(1), 85-96.

Çamlıbel-Çakmak, Ö. (2010). Okul öncesi eğitim kurumlarında aile katıllımı. Abant İzzet Baysal Üniversitesi Sosyal Bilimler Enstitïsï Dergisi, 1(20), 1-17.

Çapri, B. ve Çelikkaleli, Ö. (2008). Öğretmen adaylarının öğretmenliğe ilişkin tutum ve mesleki yeterlik inançlarının cinsiyet, program ve fakültelerine göre incelenmesi. İnönü Üniversitesi Eğitim Fakültesi Dergisi, 9(15), 33-53.

Cömert, D. ve Güleç, H. (2004). okulöncesi eğitim kurumlarında aile katılımının önemi: öğretmen- aile - çocuk ve kurum. Afyon Kocatepe Üniversittesi Sosyal Bilimler Dergisi, 6(1), 131-145.

Demirtaş, H. Cömert, M. ve Özer, N. (2011). Öğretmen adaylarının öz-yeterlik inançları ve öğretmenlik mesleğine ilişkin tutumları. Ë̆itim ve Bilim Dergisi, 36(159), 96-111.

Deniz, S. ve Tican, C. (2017). Öğretmen adaylarının öğretmen öz-yeterlik inançları ile mesleki kaygilarına yönelik görüşlerinin incelenmesi. Abant İzzet Baysal Üniversitesi Ë̆itim Fakültesi Dergisi, 17(4), 1838-1859.

Doğan, T. ve Çoban, A. E. (2009). Eğitim fakültesi öğrencilerinin öğretmenlik mesleğine yönelik tutumları ile kayg1 düzeyleri arasındaki ilişkinin incelenmesi. Ĕ̈̆tim ve Bilim Dergisi, 34(153), 157-168.

Dolapçı, S. ve Yıldız-Demirtaş, V. (2016). Öğretmen adaylarının öz-yeterlilik algıları ve kaynaştırma eğitimine bakış açıları. Batı Anadolu Eg̈itim Bilimleri Dergisi, 7(13), 141 - 160.

Dursun, S. ve Karagün, E. (2012). Öğretmen adaylarının mesleki kaygı düzeylerinin incelenmesi: kocaeli üniversitesi beden eğitimi ve spor yüksekokulu son sınıf öğrencileri üzerine bir araştırma. Kocaeli Üniversittesi Sosyal Bilimler Dergisi, 24(1), $93-112$.

Edutopia, (2000). Parental involvement reaps big benefits. https://www.edutopia.org/parent-involvement-reaps-bigbenefits. Erişim Tarihi: 02.01.2019.

Ekinci, N. (2015). Öğretmen adaylarının öğrenme yaklaşımları ve öğretmen öz-yeterlik inançları arasındaki ilişki. Hacettepe Üniversitesi Eğitim Fakültesi Dergisi, 30(1), 62-76. 
Ekinci-Vural, D. ve Hamurcu, H. (2008). Okul öncesi öğretmen adaylarının fen öğretimi dersine yönelik öz-yeterlik inançlar1 ve görüşleri. İlk.̈̈gretim Online Dergi, 7(2), 456-467.

Ekinci-Vural, D. ve Kocabaş, A. (2016). Okul öncesi eğitim ve aile katılımı. Elektronik Sosyal Bilimler Dergisi,15(59), 1174-1185.

Gerçek, M. (2018). Mesleki kayg1 ve kariyer uyumluluğu arasındaki ilişkiler: öğretmen adayları açısından bir inceleme. Trakya Üniversitesi Sosyal Bilimler Dergisi, 20(2), 297-312.

Gonzalez-DeHass, A. R., Willems, P. P. ve Doan Holbein, M. F. (2005). Examining the relationship between parental involvement and student motivation. Educational Psychology Review, 17(2), 99-123.

Gömleksiz, M. N. ve Serhatlığlu, B. (2013). Okul öncesi öğretmenlerinin öz-yeterlik inançlarına ilişkin görüşleri. International Periodical For The Languages, Literature and History of Turkish or Turkic, 8(7), 201-221.

Gümrükçü-Bilgici, B. ve Deniz, Ü. (2016a). Okul öncesi öğretmen adaylarının mesleki kaygılarının bazı demografik özelliklere göre incelenmesi. Cumburiyet International Journal of Education, 5(1), 53 - 70.

Gümrükçü-Bilgici, B. ve Deniz, Ü. (2016b). Okul öncesi öğretmen adaylarının gelecek kaygılarının incelenmesi. Kastamonu Eğitim Dergisi, 24(5), 2353-2372.

Jianfang, L. (2008). A comparison of teacher candidates and first-year teachers by gender and licensure level, in terms of their perceptions of preparation program quality, efficacy beliefs, and concerns about teaching. http://rave.ohiolink.edu/etdc/view?acc_num $=$ osu1225902746. ErişimTarihi: 28.06.2019.

Kafkas, M. E., Açak, M., Çoban, B. ve Karademir, T. (2010). Beden eğitimi öğretmen adaylarının öz-yeterlik algıları ile mesleki kaygılları arasındaki ilișki. İnönü Üniversitesi Ĕ̈itim Fakültesi Dergisi, 11( 2), 93-111.

Kahraman, Ü. ve Çelik, K. (2019). Eğitim fakültesi formasyon öğrencilerinin öz-yeterlik inançları ile mesleki kayg1ları arasındaki ilişki. Pamukkeale Üniversitesi Ë̆itim Fakültesi Dergisi, 45(1), 353-375.

Kalayc1, S.. (Ed.) (2008), Spss uygulamal çok değiskenli istatistik teknikleri. Ankara: Asil Yayın Dağıtım.

Kalemoğlu-Varol, Y., Erbaş, M. K ve Ünlü, H. (2014). Beden eğitimi öğretmen adaylarının mesleki kayg1 düzeylerinin öğretmenlik mesleğine yönelik tutumlarını yordama gücü. Ankara Üniversitesi Spor Bilimleri Fakültesi, 12(2), 113-123.

Karasar, N. (2012). Bilimsel araștırma yöntemi. Ankara: Nobel Yayınc1lık.

Kesgin, E. (2006). Okul öncesi eğitim ögretmenlerinin öz yeterlilik düzeyleri ile problem çözme yaklaşmlarm kullanma düzeyleri arasındaki ilişkinin incelenmesi (deniz̧li ili örneği)(Yüksek Lisans Tezi). Pamukkale Üniversitesi Sosyal Bilimler Enstitüsü, Denizli.

Köklükaya, A. ve Güven-Yıldırım, N. E. (2016). Öğretmenlik mesleğine yönelik kaygı ölçeğinin geliştirilmesi ve fen bilgisi öğretmen adaylarının kaygı düzeylerinin belirlenmesi. Uluslararası Sosyal Araştırmalar Dergisi, 9(43),14541462.

Marso, Ronald N. ve Pigge, Fred L. (1990). Relationships between prospective teachers' personality attributes and changes in concerns about teaching during training. Annual Meeting of the Mid-Western Educational Research Association Chicago, IL, October 17-20.

Ogelman, H. (2014). Okul öncesi eğitim kurumlarında aile katılımı çalışmaları: denizli ili örneği. Adıyaman Üniversitesi Sosyal Bilimler Enstitüsü Dergisi, 7(17), 259-284.

Özen, F. (2018). Okul öncesi ögretmenleri aile katılım çalşsmalarna yönelik öz-yeterlik inançlarnm incelenmesi (Tezsiz Yüksek Lisans Dönem Projesi). Pamukkale Üniversitesi Eğitim Bilimleri Enstitüsü, Denizli.

Randi, J. (2004). Teachers as self-regulated learners. Teachers College Record, 106(9), 1825-1853.

Taşkın, Ç. Ş. ve Hacıömeroğlu, G. (2010). Öğretmen öz-yeterlik inanç ölçeğinin türkçeye uyarlanması ve sınıf öğretmeni adaylarının öz-yeterlik inançları. Dokuz Eylül Üniversitesi Buca Ë̆itim Fakültesi Dergisi, 27(10), 63-75.

Türkdoğan, S. C. (2014). Öğretmen adaylarnm ögretmenlik mesleğini tercih etmelerinde etkili olan faktörlere göre mesleki kaygzlar(Yüksek Lisans Tezi). Pamukkale Üniversitesi Eğitim Bilimleri Enstitüsü, , Denizli.

Uygun, K., Avaroğulları, M ve Oran, M. (2016). Sosyal bilgiler öğretmen adaylarının mesleki kayg1 düzeylerinin incelenmesi. International Periodical for the Languages, Literature and History of Turkish or Turkic,11(21), 417-436.

Uysal, B. (2018). Örgütsel Adalet üzerinde yansı̨̧lk ilkesinin etkisini belirlemeye yönelike özel hastanelerde yapılan bir araştırma(Doktora Tezi). Marmara Üniversitesi, Sağlık Bilimleri Enstitüsü, İstanbul.

Ünüvar, P. (2010). Aile katılımı çalışmalarına yönelik ebeveyn ve öğretmen görüşlerinin karşılaştırılması. Kastamonu Ë̆itim Dergisi, 18(3), 719-730.

Yaşar-Ekici, F. (2017a). Okul öncesi eğitim kurumlarındaki aile katılım çalışmalarına katılan ve katılmayan ailelerin çocuklarının sosyal beceri ve problem davranışları arasındaki ilişki. Hitit Üniversitesi Sosyal Bilimler Enstitüsï Dergisi, 1(1), 543-561.

Yaşar-Ekici, F. (2017b). Okul öncesi öğretmen adayları ile pedagojik formasyon eğitimi alan öğretmen adaylarının öğretmenliğe yönelik öz yeterlik inançlarının karşılaştıılması. Insan ve Toplum Bilimleri Araştırmalar Dergisi, 1(1), 543-561.

Yenice, N. (2012). Öğretmen adaylarının öz -yeterlik düzeyleri ile problem çözme becerilerinin incelenmesi. Elektronik Sosyal Bilimler Dergisi, 11(39), 36-58.

Yeşilyurt, E. (2013). Öğretmen adaylarının öğretmen öz-yeterlik algıları. Elektronik Sosyal Bilimler Dergisi, 12(45), 88104. 


\section{EXTENDED ABSTRACT}

Teachers educate their children so that they can be active members in the structure of society. To increase students' motivation, to maintain effective classroom management, to plan activities and courses and similar subjects are the responsibility of teachers. Studies researching teachers' competence show that self-efficacy is a fundamental determinant of teachers' effectiveness (Randi, 2004). Teachers should have a high level of self-efficacy belief that they will receive qualified training and fulfill the responsibilities required by their profession in order to successfully pursue their profession. Therefore, the level of teachers' self-efficacy beliefs should be determined while continuing their professional education. At the same time, it should be ensured that prospective teachers graduate with high self-efficacy beliefs through the necessary arrangements to be made in the teacher training program. Belief in self-efficacy towards family involvement, which is a special area of self-efficacy, is the teacher candidates' judgments about their own competence that they can effectively and efficiently conduct communication and family education activities with the family (Ateş, \& Kalburan, 2016). Self-efficacy beliefs of teachers who are highly effective in the field of education and training of individuals and the factors affecting these beliefs have gained importance (Gömleksiz, \& Serhatlığlu, 2013). It is thought that teachers' concerns about the profession will have an impact on the ability of teachers to conduct effective family involvement activities.

Therefore, in this study, it was aimed to research the relationship between pre-school teacher candidates' professional concerns about teaching profession and self-efficacy beliefs for family involvement activities. The population of the study consists of pre-school teacher candidates who are educated at Necmettin Erbakan University in 2018- 2019. The sample group consisted of 211 students who voluntarily agreed to participate in the study. This study used survey method. The research data were collected by Self-Efficacy Belief Scale for Family Involvement Activities of Pre-school Teacher Candidates developed by Ateş and Kalburan (2016) and by means of "Anxiety Scale for Teaching Profession " developed by Köklükaya and Yildırım (2016) and Personal Information Form developed by the researchers. Kolmogorov-Simirnov and Shapiro Wilk tests were performed to determine whether the obtained data were distributed normally. It was detected that the data were not normally distributed and for the nonparametric tests the Bonferronni test and Spearman Correlation analysis tests were used by Mann Whitney U, Kuruskall Wallis $\mathrm{H}$ in order to determine the source of the difference between the groups.

As a result of the findings, it was found that the pre-school teacher candidates' anxiety scores for the teaching profession were at the level of "I disagree" and the self-efficacy beliefs for the family involvement activities were" I feel sufficient". In this case, it can be said that pre-school teacher candidates' anxiety levels towards teaching profession are low and self-efficacy belief level scores for family involvement activities are high. At the same time, it was determined that students' self-efficacy beliefs related to professional anxiety levels and family involvement activities had a negatively moderate level of negative relationship. According to this result, it can be said that pre-school teacher candidates' self-efficacy beliefs towards family involvement activities increase and their professional anxiety decreases. At the same time, it can be said that pre-school teacher candidates' anxiety about their professions has an effect on their self-efficacy towards family involvement activities. In addition, it was found that these skills did not show significant differences in terms of gender, age and high school variables graduated. According to this result, it can be said that gender and age are not decisive on these skills and the education given is more decisive. However, it can be said that the vocational education given in the undergraduate program is more decisive for vocational anxiety and self-efficacy belief than the high school education. It was determined that pre-school teacher candidates' professional concerns about teaching profession and self-efficacy beliefs related to family involvement activities showed significant difference according to teaching level variable. The anxiety levels of the 2 nd grade students towards the profession were found to be higher than the 1st grade students. It can be said that as this difference is higher than the first year vocational courses in the 2nd grade and that students' anxiety increases as a result of the awareness of the importance of the teaching profession. According to the results of this research, preschool teacher candidates' studies can be done by reducing their concerns and increasing self-efficacy beliefs for family involvement activities. In order to reduce pre-school teacher candidates' professional anxiety during the undergraduate education process and to increase self-efficacy towards family involvement activities, more emphasis can be placed on practice courses in schools. Research on preschool teacher candidates' professional anxiety and self-efficacy beliefs related to family involvement activities can be done with pre-school teacher candidates at different universities. 